\title{
The Journal of THORACIC AND CARDIOVASCULAR SURGERY
}

\section{THE AMERICAN ASSOCIATION FOR THORACIC SURGERY}

\author{
1999 AATS SCIENTIFIC ACHIEVEMENT AWARD RECIPIENT—MICHAEL E. DEBAKEY, MD
}

W e are very pleased to present the Scientific Achievement Award of The American Association for Thoracic Surgery for 1999 to Michael E. DeBakey, MD, of Houston, an award presented only 2 previous times. Dr DeBakey is internationally recognized as the consummate cardiovascular surgeon, an ingenious medical inventor and innovator, a gifted and dedicated teacher, and an international medical statesman.

It is appropriate that we are honoring Dr DeBakey in Louisiana. Dr DeBakey was born in Lake Charles, Louisiana, close to New Orleans. He received his bachelors and MD degrees from Tulane University in this city. He also completed his internship at Charity Hospital in New Orleans and his residency in surgery at Charity Hospital, at the University of Strasbourg under Professor René Leriche, and at the University of Heidelberg in Germany under Professor Martin Kirschner. In 1937, Dr DeBakey joined the faculty of Tulane University here in New Orleans. He was in the military service during World War II and was director of the Surgical Consultants' Division in the surgeon general's office. He reached the rank of colonel in the US Army. His work in the surgeon general's office led to the development of the mobile army surgical hospital, otherwise known as MASH units.

J Thorac Cardiovasc Surg 1999;118:989-90

Copyright (C) 1999 by Mosby, Inc.

$0022-5223 / 99 \$ 8.00+0 \quad \mathbf{1 2 / 1 / 1 0 1 9 2 5}$
After the war, Dr DeBakey returned to Tulane as associate professor of surgery, and in 1948 he accepted the chairmanship of the Department of Surgery at Baylor University College of Medicine in Houston, thus beginning a 51-year commitment to that university and city. He was subsequently named president of the newly formed Baylor College of Medicine. In 1979 he became chancellor of the college and in 1996, chancellor emeritus.

Dr DeBakey's achievements are too numerous to name, but his expertise has been in medical device innovation beginning with the invention of the roller pump, development of Dacron and Dacron velour artificial grafts replacing diseased arteries, and development of carotid endarterectomy. He had several firsts in operations on the vascular system, especially the thoracic aorta. He was the first to use a left ventricular assist device, and his continued work in this area last year yielded a series of successful implants in Germany. He has participated in more than 50,000 cardiovascular operations.

As a medical statesman, he has served as an advisor to almost every president in the past 50 years and heads of state throughout the world, the last of which was Boris Yeltsin of Russia. Dr DeBakey helped to establish the National Library of Medicine at the National Institutes of Health and was recently president of the board of regents. He established the president's Commission on Heart Disease, Cancer and Stroke and has numerous consultative appointments to the 
National Heart, Lung, and Blood advisory council of the National Institutes of Health.

He has written or edited 1400 medical articles, chapters, and books, including a new one titled, The New Living Heart. He is also the founder and the first editor of The Journal of Vascular Surgery and was editor of the Yearbook of General Surgery for many years. He has been on the editorial boards of numerous journals. He has at least 50 honorary degrees and a number of important awards from governments all over the world. In 1969, President Lyndon Johnson bestowed on him the highest honor a US citizen can receive, the Presidential Medal of Freedom with Distinction. In 1987, President Ronald Reagan awarded him the National Medal of Science.
Suffice it to say, Dr DeBakey is one of the most important leaders in cardiovascular surgery of this century. His keen intellect, professional ingenuity, integrity, and selfless devotion to the service of humanity have made him a true legend in his own time. It is also most fitting that Dr Michael DeBakey was president of The American Association for Thoracic Surgery in 1959, exactly 40 years ago. It is our honor to name Dr Michael E. DeBakey of Houston, Texas, as the recipient of the 1999 Scientific Achievement Award of The American Association for Thoracic Surgery. 